Abant Tıp Dergisi

Araştırma Makalesi / Cilt 9 Sayı 2 Yıl 2020
Abant Medical Journal

Research Article /Volume 9 Issue 2 Year 2020

\title{
Monosit Sayısının Yüksek Yoğunluklu Lipoproteine Oranı Akut İskemik İnmede Inflamasyon Belirteci Midir?
}

Is the Ratio of Monocyte Count to High Density Lipoprotein an Indicator of Inflammation In Acute Ischemic Stroke?

Behiye Deniz Kosovalı

Ankara Şehir Hastanesi, Yoğun Bakım Kliniği, Ankara - Türkiye

Öz

GiRiş ve AMAÇ: Bu çalışmanın amacı akut iskemik strok hastalarında monosit sayısının yüksek dansiteli lipoproteine (HDL) oranının bir belirteç olup olmadığını saptamak.

YÖNTEM ve GEREÇLER: Dahiliye yoğun bakım kliniğinde akut iskemik strok ile takip edilen elli hasta (Grup 1) ile dahiliye polikliniğine başvuran elli sağlıklı kişinin (Grup 2) dosya kayıtları retrospektif olarak taranarak çalışmaya dahil edildi. Her iki grupta hastaların demografik özellikleri ve laboratuvar sonuçları dosya kayıtlarından tarandı. Monosit sayısının HDL'ye oranı değerlendirildi. İstatistiksel olarak anlamlılık $p<0.005$ olarak kabul edildi.

BULGULAR: Ortalama yaş grub 1 'de $78.45 \pm 12.55$; grup 2'de $76.93 \pm 8.69$ idi $(p=0.306)$. Erkek cinsiyet $\% 56(n=28), \% 48$ $(n=24)$ ve $(p=0.423)$ (sırasıyla grup1, grup 2$)$. Lökosit sayısı, HDL düzeyi, monosit sayısının HDL'ye oranı grup 1 'de grup 2 'den yüksekti ve istatistiksel olarak anlamlılık saptandı ( $p=0.002,0.002,0.003$, sırasıyla). Hastaların yoğun bakımda kalış gün sayısı $11.38 \pm 7.540$ gün ve mortalite oranı $\% 34$ ( $n=17$ ) olarak saptandı.

TARTIŞMA ve SONUÇ: Kardiyak iskemilerdeki gibi benzer patolojiye sahip olduğu düşünülen akut iskemik stroklarda monosit sayısının HDL oranı kronik inflamasyonun bir göstergesi olarak kullanılabilir.

Anahtar Kelimeler: Akut iskemik strok, HDL, monosit sayısı, yoğun bakım

\section{Abstract}

INTRODUCTION: The aim of this study is to determine whether the ratio of monocyte count to high density lipoprotein (HDL) is an indicator in acute ischemic stroke patients.

METHODS: Fifty patients (Group 1) followed by an acute ischemic stroke at the internal medicine care unit and fifty healthy individuals (Group 2) who applied to the internal medicine outpatient clinic were retrospectively scanned and included in the study. The demographic characteristics and laboratory results of the patients in both groups were scanned from the file records. The ratio of monocyte count to HDL was evaluated. Statistical significance was accepted as $\mathrm{p}<0.005$.

RESULTS: The mean age was $78.45 \pm 12.55$ in group 1 ; in group 2 it was $76.93 \pm 8.69(p=0.306)$. Male gender $56 \%$ ( $n$ $=28), 48 \%(n=24)$ and $(p=0.423)$ (group1, group 2 , respectively). The leukocyte count, $\mathrm{HDL}$ level, and the ratio of monocyte count to HDL were higher in group 1 than in group 2 and statistically significant $(p=0.002,0.002,0.003$, respectively). Length of stay in intensive care unit of patients was $11.38 \pm 7.540$ days and the mortality rate was $34 \%(n=17)$.

DISCUSSION and CONCLUSION: In acute ischemic strokes, which are thought to have similar pathology, as in cardiac ischemia, the ratio of monocyte count to HDL can be used as a hall-mark of chronic inflammation.

Keywords: Acute ischemic stroke, HDL, monocyte count, intensive care

\section{GíRiş}

Serebrovasküler hastalıklar (SVH) sıklıkla ileri yaş popülasyonda görülen, morbidite ve mortalitesi yüksek olan, yoğun bakım ünitelerindeki hastaların önemli bir grubunu oluşturan nörolojik hastalıklar arasındadır. SVH'ın \%85'ini iskemik, $\% 15^{\prime}$ ini hemorajik nedenler oluşturur. SVH nedenleri arasında büyük bir grubu oluşturan iskemik inme patogenezinde de kardiyovasküler hastalıklar gibi kronik inflamasyon ve ateroskleroz en sık rastlanan nedenlerdir. Aterosklerotik lezyon kronik inflamatuvar bir süreçtir. Bu sürece damar endotel hasarı, monositler/makrofajlar, düz kas hücreleri, bazı büyüme faktörleri ve sitokinler katılır (1).

Benzer patogeneze sahip olmalarından yola çıkarak, son günlerde kardiyovasküler sistem hastalıklarında öne çıkan ve inflamatuar belirteç 
olan monosit/high-density lipoprotein (HDL) kolesterol oranının akut iskemik inme (Aii) hasta grubunda da benzer etkiye sahip olacağını düşünerek bu çalışmada akut iskemik inme hastalarında da monosit/HDL oranını (MHO) inflamatuar belirteç olarak saptamayı amaçladık.

\section{GEREÇ ve YÖNTEMLER}

Çalışmada Dahiliye Yoğun Bakım Ünitesinde (DYBÜ) 1 Ocak 2015-1 Ekim 2018 tarihleri arasında Aii tanısı ile kabul edilen 105 hastanın dosyaları incelendi ve araştırma insan deneylerinden sorumlu komitenin etik standartlarına ve Helsinki beyannamesine uygun olarak yapıldı. Yoğun bakım ünitesinde (YBÜ) takip edilen, ilk 24 saat içinde tam kan ve lipid profili olan elli hasta çalışmaya alındı (Grup1). Kontrol grubu ise dahiliye polikliniğine ayaktan başvuran hastalar retrospektif olarak tarandı ve anamnezinde tanı almış herhangi bir hastalığı bulunmayan ve herhangi bir nedenle ilaç kullanmayan, eş zamanlı bakılan tam kan ve lipid profil sonuçları olan elli hastadan oluşturuldu (Grup2). Grupların demografik özellikleri, lökosit, monosit, trombosit (PLT) sayıları, hematokrit $(\mathrm{Htc}), \mathrm{HDL}$, düşük-dansiteli lipoprotein (LDL) değerleri ve MHO karşılaştırıldı. Ayrıca hasta grubunun yoğun bakım ünitesinde kalış süresi ve mortalite oranları incelendi. İstatistiksel veriler SPSS programı ile elde edildi ve veriler sayı ve yüzde olarak bildirildi.

\section{BULGULAR}

Toplam 100 olgunun incelendiği çalışmada her bir gruptaki hasta sayısı ellidir. Grup1 ve 2'nin yaş ortalamaları sırasıyla 78.45 \pm 12.55 (min:32$\max : 91), \quad 76.93 \pm 8.69 \quad(\min : 45-\max : 94) \quad$ idi. Grup1'de erkek cinsiyet \%56 ( $n=28)$, kadın cinsiyet $\% 44(n=22)$, grup2'de erkek cinsiyet $\% 48$ $(n=24)$, kadın cinsiyet $\% 52(n=26)$ idi. Her iki grubun yaş ve cinsiyet dağılımı benzerdi $(p=0.306, p=0.423)$. Grupların lökosit, Htc, PLT, monosit, HDL ve MHO oranı değerlerinin ortalama \pm standart sapma ve $p$ değerleri Tablo 1'de belirtilmiştir. Hasta grubunun yoğun bakımda yatış süresi ortalama $11.38 \pm 7.540$ gün (min:1- max:31), mortalite oranı ise \%34 ( $n=17)$ saptandı.

Tablo 1. Grup1 (hasta) ve Grup2 (kontrol)'nin laboratuvar değerleri ve aradaki ilişki, $p<0.005$ değerleri istatistiksel olarak anlamlı kabul edildi

\begin{tabular}{|c|c|c|c|}
\hline Değişken & Grup1 $(n=50)$ & Grup2 $(n=50)$ & $\begin{array}{l}p \\
\text { değeri }\end{array}$ \\
\hline Lökosit & $5447,98 \pm 4586,036$ & $7580,00 \pm 1948,023$ &, 002 \\
\hline Htc (\%) & $46,08 \pm 51,774$ & $40.94 \pm 5.55$ & ,076 \\
\hline PLT & $276,14 \pm 114,943$ & $246,86 \pm 55,728$ & ,374 \\
\hline Monosit & $807,90 \pm 750,389$ & $601,00 \pm 150,757$ & ,363 \\
\hline $\mathrm{HDL}(\mathrm{mg} / \mathrm{dL})$ & $39,02 \pm 9,970$ & $46,04 \pm 8,638$ & ,000 \\
\hline LDL (mg/dL) & $110,56 \pm 35,246$ & $108,62 \pm 22,500$ & ,744 \\
\hline TG (mg/dL) & $119,98 \pm 49,813$ & $113,66 \pm 49,421$ & ,725 \\
\hline $\mathrm{MHO}$ & $18,9624 \pm 10,67138$ & $13,6284 \pm 5,00922$ & ,003 \\
\hline
\end{tabular}

\section{TARTIŞMA}

$\mathrm{Bu}$ çalışmadaki amacımı MHO iskemik inme grubundaki hastalarda inflamasyonun göstergesi olarak kontrol grubuna göre yüksek olduğunu saptamaktı. Elde edilen sonuçlar da bizim hipotezimizi destekler nitelikte $\mathrm{MHO}$ grup1'de grup2'ye göre daha yüksek bulundu $(18.9,13.6)$ ve bu fark istatistiksel olarak anlamlıdır $(p=0.003)$.

Yine grup1'de ateroskleroza yatkınlığı arttıran düşük HDL düzeyi ile uyumlu olarak grup1'de $(39.02 \mathrm{mg} / \mathrm{dL})$ grup2'den $(46.04 \mathrm{mg} / \mathrm{dL})$ daha düşük olduğu saptandı ve istatistiksel olarak anlamlılık vardı $(p=0.000)$.

Buna karşlık aterosklerozun inflamasyon sürecinde rol oynayan monosit sayısı her ne 
kadar grup1'de (807.9) grup2'den (601.0) fazla olsa da arada istatistiksel olarak anlamlı fark saptanmadı $(p=0.393)$. Ateroskleroz kronik bir inflamatuar süreçtir ve aterosklerozda monositler inflamasyonla ilişkili birçok sitokinin kaynağıdır. KAH'nda monosit ve diferansiye makrofajların inflamatuar sitokinleri ve doku remodelingini düzenlediği bildirilmiştir (2).

Lipidlerde biriken monositler makrofajlara dönüşerek ateroskleroza neden olan elastaz ve kollajenzı da içeren metalloproteinazların salınımını gerçekleştirir (3). Bunun yanında, HDL'nin major fonksiyonu ise kolesterolu yok ederek, monosit aktivasyonunu, monosit progenitor hücrelerinin proliferasyon ve diferansiasyonunu suprese ederek periferal dokuyu korumaktır (2). Ateroskleroz gelişiminde lipid profilinin önemi günümüzde oldukça iyi bilinen risk faktörleri arasındadır. İnflamasyon ve lipid birikimi aterosklerozdaki iki karakteristik özelliktir. İnflamasyon sadece lokal olarak değil sistemik olarak inflamatuar mediatörleri arttıran bir durum olarak değerlendirilebilir (4). Genellikle yüksek LDL ve TG düzeyi ile düşük $H D L$ düzeyi ateroskleroza yatkınlıkta karakteristik bir lipid düzeyi profilidir. Aterosklerozda makrofajlar modifiye LDL'yi ortadan kaldırır ve inflame dokulardan inflamatuar sitokinlerin salınımını sağlar (4).

HDL'nin ateroskleroza karşı koruyucu etkisinin olduğu birçok çalışma ile gösterilmiştir. En iyi bilinen etkisi ise hücrelerden kolesterolün dışarı atılmasını desteklemesidir. Böylece arter duvarlarında köpük hücre birikimi en aza indirgenir. Ayrıca, HDL antiaterojenik özelliğini monositlerin proinflamatuar ve pro-oxidant etkisini makrofaj göçünü inhibe ederek nötralize eder. Kısaca HDL antiinflamatuar, antioksidan ve antitrombotik etkiye sahiptir $(4,5,6)$.

Dolayısıyla düşük HDL düzeyi ateroskleroza ve gelişebilecek birçok vasküler kaynaklı hastalıklara neden olabilir. Bolayır ve ark. çalışmasında da hasta grubu olarak seçilen akut iskemik inme tanılı hastalarda monosit sayısı yüksek ve HDL düzeyi düşük ve $\mathrm{MHO}$ yüksek olarak bulunmuştur (7). Bu sonuçlar bizim çalışmamızın sonuçlarını destekler niteliktedir. Literatürde etyolojisinde ateroskleroz olan KAH ile MHO ilişkili çalışmaların sayısı oldukça fazla olduğu dikkatimizi çekmiştir. $\mathrm{KAH}^{\prime}$ da da akut iskemik inmedeki gibi monosit sayıları yüksek, HDL düzeyi düşük ve dolayısıyla MHO yüksek olduğu sonuçlarda belirtilmiştir $(2,8)$.

Sonuç: Bu çalışma aterosklerozun akut iskemik inmede de önemli olduğuna birkez daha vurgu yaparak kronik inflamasyon belirteci olarak MHO'nun kullanılabileceğini desteklemektedir.

Kısıtlııı: Çalışmanın tek merkezli olması, çalışmaya alınan hasta sayısının az olması, her iki grubun yaş ortalamasının yüksek olması, ek hastalık bilgilerinin yer almaması, etyolojiye yönelik verilerin eksikliği çalışmanın kısıtlılıklarıdır.

Bilgilendirilmiş Onam: Katılımcılardan yazılı onam alınmıştır.

Çıkar Çatışması: Yazarlar çıkar çatışması beyan etmemişlerdir.

Finansal Destek: Yazarlar finansal destek beyan etmemişlerdir.

\section{KAYNAKLAR}

1. Tanrıverdi B, Tetik ŞS, Aterosklerozun Patofizyolojisi ve Risk Faktörleri. Marmara Pharmaceutical Journal 2017; 21: 1-9.

2. Serçelik $A$, Besnili $A B$, Increased monocyte to high-density lipoprotein cholesterol ratio is associated with TIMI risk score in patients with ST-segment elevation myocardial infarction. Rev Port Cardiol. 2018;37(3):217-23.

3. Kızılgül M, Çalışkan M, Uçan B Monocyte to HDL Cholesterol Ratio and its association with cardio-metabolic risk factors in Primary Hyperparathyroidism. Medeniyet Medical Journal 2018;33(2):94-9.

4. Barter PJ, Nicholls S, Rye KA, Antiinflammatory properties of HDL. Circ Res. 2004 Oct 15;95(8):764-72.

5. E. Idzkowska, A. Eljaszewicz, P. Miklasz, The Role of Different Monocyte Subsets in the Pathogenesis of Atherosclerosis and Acute Coronary Syndromes. Scandinavian Journal of Immunology, 2015, 82, 163-73.

6. Ganjali S, Ruscica M, Atkin SL, Monocyte-to-HDL- 
cholesterol ratio as a prognostic marker in cardiovascular diseases. J Cell Physiol. 2018; 233(12):9237-46.

7. Bolayir A, Gokce SF, Cigdem B, Monocyte/high-density lipoprotein ratio predicts the mortality in ischemic stroke patients. Neurol Neurochir Pol. 2018;52(2):150-5.

8. Enhos A, Cosansu K, Huyut MA, Assessment of the Relationship between Monocyte to High-Density Lipoprotein Ratio and Myocardial Bridge. Arq Bras Cardiol. 2019; 112(1):12-7. 